\title{
Further Mediterranean expansion of the non-indigenous bryozoan Celleporaria brunnea: multiple records along the Italian coasts
}

\author{
Alice Lodola, Jasmine Ferrario, Anna Occhipinti-Ambrogi \\ Department of Earth and Environmental Sciences, University of Pavia, Via S. Epifanio 14, 27100 Pavia, Italy. \\ E-mail: jasmine.ferrario@unipv.it
}

\begin{abstract}
Summary: In the framework of a wider systematic survey aimed at studying non-indigenous species in Italian harbours and marinas, the ascophoran bryozoan Celleporaria brunnea was detected for the first time in the western Mediterranean Sea. The species is presumably native to the Pacific coasts of North America and is distributed from British Columbia to the Galapagos Islands (Ecuador). In the Mediterranean Sea, C. brunnea was first recorded in 2004 in the inner part of Izmir Bay near Alsancak harbour (Turkey) and later reported along the Lebanese coasts. The species was recently detected in Cascais marina in Portugal and in the Arcachon Basin (France), documenting the first records in the eastern Atlantic. The finding in the Italian harbours of La Spezia (Liguria), Olbia (Sardinia) and Lampedusa (off Sicily) marks its western and northernmost occurrence within the Mediterranean basin. Pathways of introduction into the western Mediterranean Sea are discussed, concluding that hull fouling is the most likely vector. The species may be expected to appear soon in other harbours of the Mediterranean basin.
\end{abstract}

Keywords: fouling organisms; zoobenthos; harbours; introduced species; shipping; ship hulls.

Expansión mediterránea del briozoo introducido Celleporaria brunnea: múltiples registros a lo largo de las costas italianas

Resumen: En el marco de un estudio sistemático más amplio destinado a investigar las especies introducidas en los puertos comerciales y deportivos italianos, el briozoo ascophoro Celleporaria brunnea se detectó por primera vez en el Mediterráneo occidental. La especie es probablemente originaria de la costa pacifica de América del Norte y se distribuye desde la Columbia Británica hasta las Islas Galápagos (Ecuador). En el mar Mediterráneo, C. brunnea se registró por primera vez en 2004 en la parte interior de la bahía de Izmir, cerca del puerto de Alsancak (Turquía), y más tarde se reportó a lo largo de las costas libanesas. La especie se registró recientemente en el puerto deportivo de Cascais en Portugal y en la cuenca de Arcachon (Francia), que documenta los primeros registros en el Atlántico oriental. El hallazgo en los puertos italianos de La Spezia (Liguria), Olbia (Cerdeña) y Lampedusa (Sicilia) marca su presencia en la cuenca occidental y septentrional mediterránea. Se discuten las vías de introducción en el mar Mediterráneo occidental, llegando a la conclusión que el vector más probable es el incrustamiento en el casco de los barcos. Puede esperarse que la especie aparezca pronto en otros puertos de la cuenca mediterránea.

Palabras clave: organismos incrustantes; zoobenthos; puertos; especies introducidas; navegación; incrustamiento en el casco de los barcos.

Citation/Como citar este artículo: Lodola A., Ferrario J., Occhipinti-Ambrogi A. 2015. Further Mediterranean expansion of the non-indigenous bryozoan Celleporaria brunnea: multiple records along the Italian coasts. Sci. Mar. 79(2): 263-274. doi: http://dx.doi.org/10.3989/scimar.04174.31A

Editor: X. Turon.

Received: November 3, 2014. Accepted: March 9, 2015. Published: April 7, 2015.

Copyright: () 2015 CSIC. This is an open-access article distributed under the Creative Commons Attribution-Non Commercial License (by-nc) Spain 3.0.

\section{INTRODUCTION}

In recent years, many marine organisms have been introduced into new habitats by human-mediated transport, mostly by fouling of the hulls of ships or other submerged surfaces (e.g. anchors, buoys and nets; Carlton and Hodder 1995, Gollasch 2002, Floerl et al. 2009) and through transfer in ballast waters (Carlton 1985, Carlton and Geller 1993, Gollasch et al. 2000). To date, the maritime traffic across the oceans remains 
the most significant factor contributing to the current patterns of biogeographic distribution of many marine organisms worldwide (Carlton 1985, 1987). Many different taxa, such as algae, sponges, molluscs, polychaetes, crustaceans, bryozoans, ascidians and fish, have spread as part of the fouling community or as passengers in ballast water tanks due to their ability to survive for several weeks during transoceanic journeys (Gollasch et al. 2000).

Bryozoans are species that are particularly likely to be transported by such means because of their tendency to grow on a great variety of substrates, which makes them a major component of marine benthic hard-bottom communities worldwide (Woollacott and Zimmer 1977). In particular, cheilostome bryozoans are known to be easily dispersed as fouling organisms to non-native regions (Watts et al. 1998). Furthermore, some of them possess a planktotrophic larva that may have a potential planktonic life of up to several weeks, so their transport by ballast waters is also considered (Carlton 1985, Carlton and Geller 1993, Watts et al. 1998).

Celleporaria brunnea (Hincks, 1884) is an ascophoran bryozoan of northeastern Pacific origin, first described by Hincks (1884, as Cellepora brunnea) in British Columbia (Canada). The species is widely distributed in the Pacific Ocean; in fact it was reported in the vicinity of the Panama Canal, in the Galapagos Islands (Hastings 1929) and Ecuador (Osburn 1952, Soule et al. 1995). Furthermore, C. brunnea is one of the most abundant species in the Gulf of California (Soule 1961, Soule and Soule 1964). Recently, the species was also recorded in the Hawaiian Islands, where it may have arrived from the Californian coasts (Godwin 2003). In 2004, C. brunnea was discovered on aquaculture steel cages in southern Korea, where it was considered to have been introduced from the eastern Pacific Ocean (Seo and Min 2009). In the Mediterranean Sea, $C$. brunnea was recorded for the first time in 2004 near Alsancak harbour, in the inner part of Izmir Bay (Turkey, Aegean Sea), fouling on Mytilus galloprovincialis Lamarck, 1819 (Koçak 2007). In addition, Harmelin et al. (2009) reported the presence of the species in the coastal waters of Lebanon, on the basis of preserved material collected between the late 1990s and the early 2000s. Recently, a recent revision of nonindigenous bryozoans in the eastern Mediterranean Sea (Harmelin 2014) assigned to Celleporaria sp. aff. brunnea the specimens collected in Beirut (Lebanon) in 2003. In 2012, C. brunnea was detected in Cascais marina, located west of Estoril in the greater Lisbon area, Portugal, representing the first record of the species in the eastern Atlantic region (Canning-Clode et al. 2013). Furthermore, Harmelin (2014) assigned to C. brunnea specimens of Celleporaria aperta (Hincks, 1882) recorded by André et al. (2014) in the Arcachon Basin on the Atlantic coast of France.

Besides C. brunnea, six other species of Pacific origin belonging to the Celleporaria genus have been reported with scattered distribution in the Mediterranean Sea: Celleporaria aperta, Celleporaria fusca (Busk, 1854), Celleporaria labelligera Harmer, 1957, Celle- poraria pilaefera (Canu and Bassler, 1929), Celleporaria sherryae Winston, 2005 and Celleporaria vermiformis (Waters, 1909). C. aperta was first recorded in the Mediterranean along the coasts of Israel, where it was considered to have been introduced through the Suez Canal (Powell 1969, d'Hondt 1988). In the mid-1970s, the species was reported, together with $C$. pilaefera, on fouling cages of an oyster farm on the island of Malta, where both species were most probably introduced via shipping (Agius et al. 1977). Recently, these latter two records were considered "questionable" by Sciberras and Schembri (2007) because there are no other records of these species from Malta in the literature and it is not known whether populations of both species still persist. C. fusca was reported for the first time in the Mediterranean at Haifa Bay (d'Hondt 1988), on the basis of preserved material collected in 1974 , but no recent records have been reported (Zenetos et al. 2012). C. labelligera, $C$. sherryae and $C$. vermiformis were recently reported along the Lebanese coasts by Harmelin (2014), the former species being very common in Beirut and Tripoli harbours.

The present study is part of a wider systematic survey aimed at studying non-indigenous species in Italian commercial harbours (Lodola 2013). It documents the occurrence of $C$. brunnea in the Italian ports of La Spezia, Olbia and Lampedusa, located in the Ligurian Sea, western-central Tyrrhenian Sea, and Sicilian Channel, respectively. These findings represent the first records of this species in Italian waters and its western- and northernmost occurrence within the Mediterranean Sea. A taxonomic comparison with previous records of C. brunnea in the Mediterranean Sea and the Atlantic and Pacific Oceans is also provided. Furthermore, we discuss the most likely vectors of introduction of $C$. brunnea into the western Mediterranean basin.

\section{MATERIALS AND METHODS}

A systematic survey was carried out in two consecutive summers (2010 and 2011) in the Italian commercial harbours of La Spezia, Olbia and Lampedusa (Fig. 1, Table 1) to detect the presence of non-indigenous species in port environments. La Spezia and Olbia are two large harbours, both characterized by international trade shipping, recreational boating and aquaculture activities (mainly mariculture of the bivalves Mytilus galloprovincialis and Ruditapes philippinarum Adams and Reeve, 1850). La Spezia is located on the eastern coast of the Ligurian Sea, between Genoa and Leghorn, while Olbia is situated on the northeast coast of Sardinia and faces the western-central Tyrrhenian Sea. Lampedusa is a small island, belonging to the Pelagian Archipelago, located in the middle of the Sicilian Channel; its harbour hosts national trade ships, local fishermen and touristic boats, and military facilities. In each harbour (Fig. 2), five sampling sites were selected within a main dock: two sampling sites were identified for residential mooring (code "P") and three for transit mooring (code "TR"). The biological sampling consisted of scraping the artificial hard substratum (the concrete dock walls) just under the low tide level, with a hand-held rigid net (1 $\mathrm{mm}$ of 


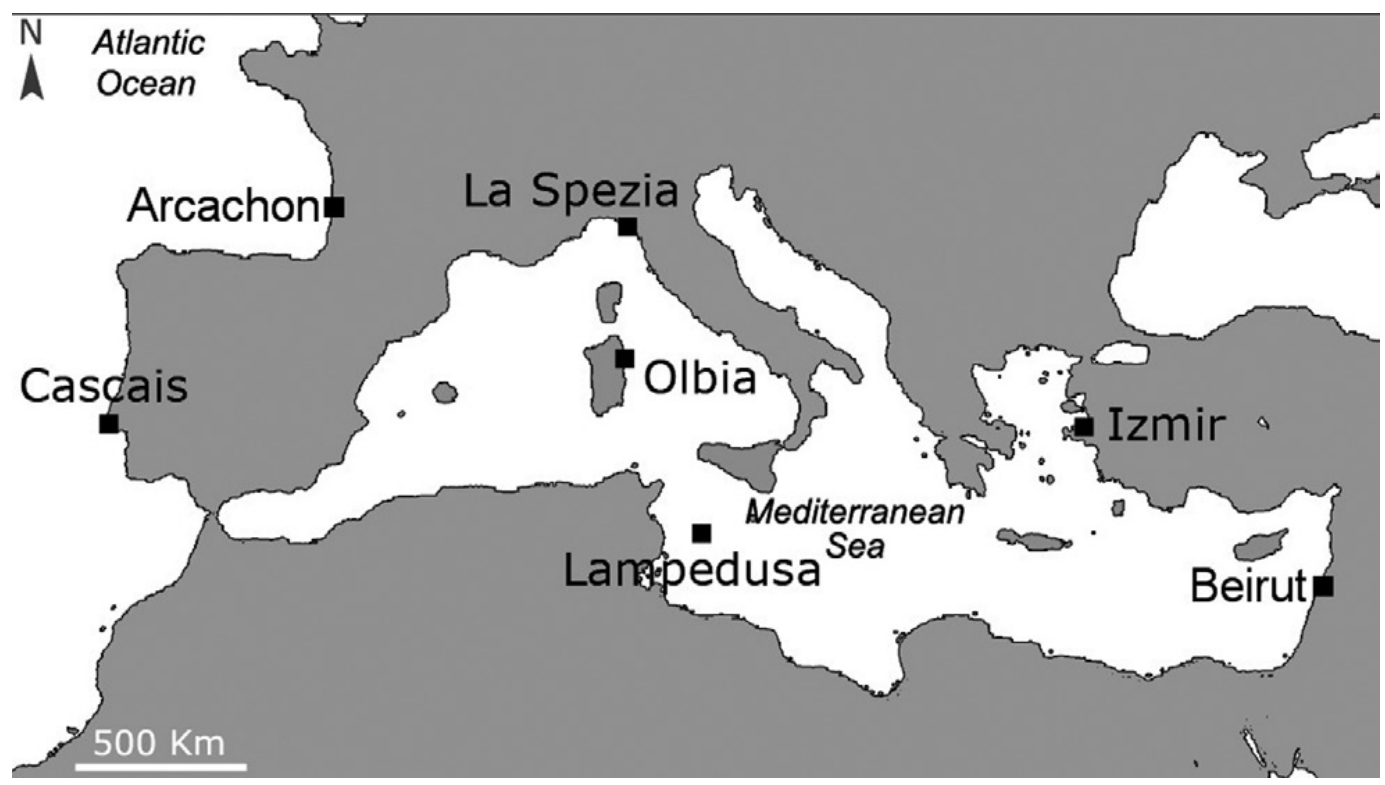

Fig. 1. - Location of the three Italian harbours investigated in the present study, La Spezia, Olbia and Lampedusa, and of the other Mediterranean and Atlantic sites where Celleporaria brunnea was detected.

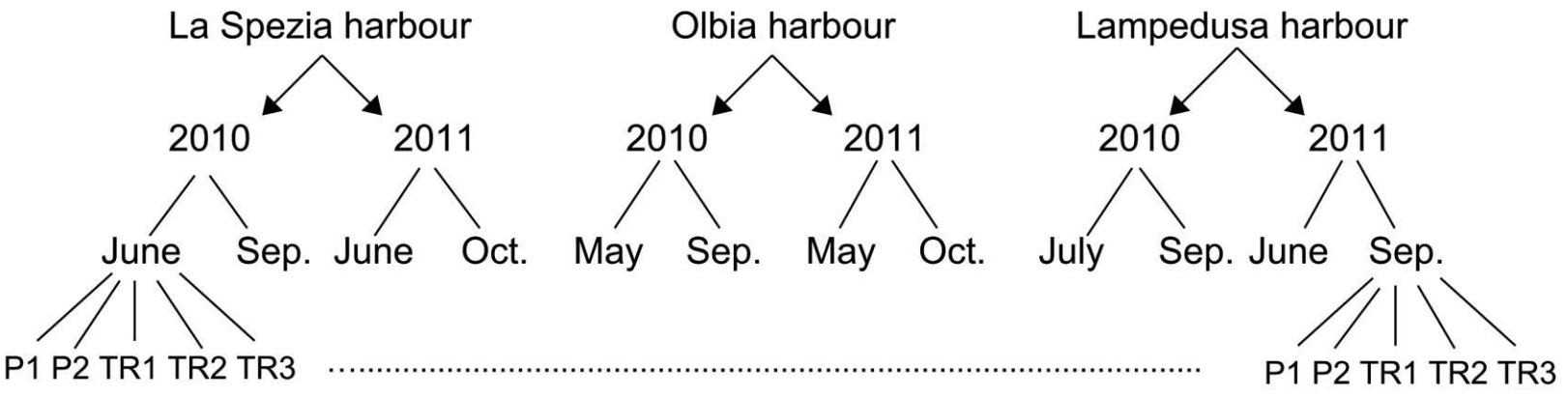

Fig. 2. - Experimental design: samples from La Spezia, Olbia and Lampedusa harbours were collected in 2010 and 2011, before and after the summer season. Five sampling sites were selected for each harbour (P1 and P2, residential moorings; TR1, TR2 and TR3, transit area moorings).

mesh size, surface $25 \times 20 \mathrm{~cm}$ ) using a semi-quantitative methodology, standardized for hard-bottom macrobenthos collections (Occhipinti-Ambrogi 2000, Marchini et al. 2004, Minchin 2007). For each sampling site, five replicates were collected in late spring/early summer, when Mediterranean benthic communities are known to exhibit their maximum development, and in late summer, just before the autumn crisis, when benthic communities decrease in biomass until the next recruitment season (Boero 1994). Because of the colonial nature of most components of the benthic fauna, the fouling community was evaluated using a semi-quantitative methodology, with a four class abundance index (ab. index) depending on coverage: + , presence of isolated colonies; ++ , a few colonies; +++, well-established colonies, and ++++ , overwhelming abundance (Occhipinti-Ambrogi 1991). This approach, already tested in other studies on the artificial hard-bottom communities (Marchini et al. 2004, Savini et al. 2006, Lodola et al. 2012) allowed us to compare the abundance of both vagile individual and colonial sessile components of the benthic fauna, whose quantitative estimation is not possible by enumeration of individuals.

Morphological measurements of some parts of zooids were made using both the microscope camera
AxioCam ERc 5s of the AxioVision Carl Zeiss Software for image analysis (accuracy $0.01 \mu \mathrm{m}$ ), and the Tescan FESEM (Field Emission Scanning Electron Microscope) series Mira 3XMU for the SEM pictures, with increasing magnification, at 6-19 mm working distance, using an accelerating voltage of $10 \mathrm{kV}$, with graphite metallization and detection by secondary electrons. Specimens used for SEM pictures were previously bleached to remove all organic residues.

\section{RESULTS}

\section{Systematics}

Superfamily LEPRALIELLOIDEA Vigneaux, 1949

Family LEPRALIELLIDAE Vigneaux, 1949

Genus Celleporaria Lamouroux, 1821

Celleporaria brunnea (Hincks, 1884)

(Figs 3, 4 and 5)

Cellepora brunnea: Hincks (1884): 56; O’Donoghue and O’Donoghue (1926): 21

Holoporella brunnea: Hastings (1929): 731, pl. 16, Figs 108-110; Osburn (1952): 496, pl. 62, figs 10-12; Soule (1961): 33; Soule and Soule (1964): 38, Figs. 13-14.

Celleporaria brunnea: Winston (1986): 12, Figs 19-22; Soule et al. 

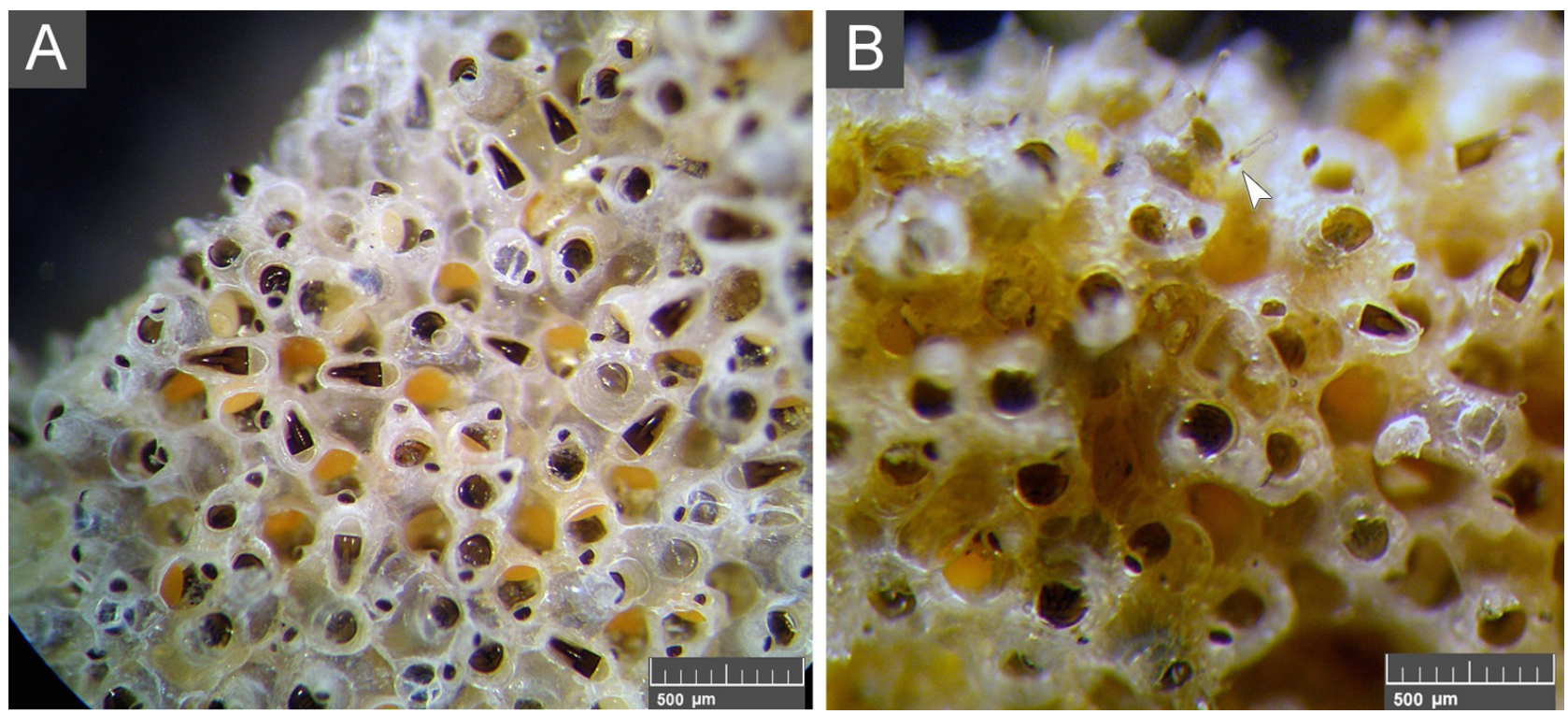

Fig. 3. - A, B. Celleporaria brunnea from the western Mediterranean Sea, showing opercula, sclerites of avicularia mandibles, base of spines (see arrow) and lophophore tentacles, dark brown in colour.

(1995): 267, Fig. 101; Koçak (2007): 191, Fig. 2 A-D; Seo and Min (2009): 29, Fig. 7; Canning-Clode et al. 2013: 2, Fig. 2 A-C.

Celleporaria aperta: André et al. (2014): 181.

Celleporaria sp. aff. brunnea: Harmelin (2014): 316, Fig. 6 A-C.

Material examined. Encrusting colonies of Celleporaria brunnea were found in the samples collected in the 2010 and 2011 campaigns in the harbours of La Spezia, Olbia and Lampedusa (Fig. 1). They were present in 15 (La Spezia), 15 (Olbia) and 9 (Lampedusa) out of the 20 samples collected in each harbour in the two sampling years. Table 1 summarizes the details of sample collection, reporting dates, locations, sites replicates, and geographical coordinates of the sampling campaigns.

Diagnosis. Unilaminar or multilaminar colonies greyish-dark brown, but occasionally entirely white. Opercula, sclerites of avicularia mandibles, base of spines and lophophore tentacles dark brown (Fig. 3A, B). Zoarium usually forms rough nodules or massive bases erratically oriented. Zooecia are moderately large and irregular in shape (Fig. 4A), exhibiting erect structures oriented in every direction. Inflated interzooidal boundaries with more than ten areolar pores (Fig. 4B); smooth or granular surface, occasionally ribbed. Orifice proximal border, with a midline notch ('pseudosinus'), bounded by small horizontal shelf-like condyles, never closing the 'pseudosinus' (Fig. 4B). The peristome, which is thin and moderately raised, usually bears a pair of spines (Fig. 4C), black jointed at the base, (Fig. 3B) positioned on opposite sides, with occasionally one to three smaller ones between them. Suboral avicularia (Fig. 4D) proximal to the orifice variable: small non-erected or cylindrical erected. The nearly semicircular mandible of suboral avicularia may vary in size and raise with dentate beak (6-9, Fig. 4E). Interzooidal avicularia large and scattered, subspatulate, sclerites of mandibles spade-shaped and dark brown in colour (Figs 3A and 5A, B); fully formed beak turns upward at the tip. Ovicell hood-shaped and imperforate (Fig. 5C). The irregular shape of C. brunnea zooids, vertically heaped and erratically oriented, making it difficult sometimes to get measurements of colony and zooids parameters. For this reason, only interzooidal avicularia and primary orifice dimensions (length and width) are reported here (Table 2).

Remarks (Tables 2 and 3). Morphological characters described for our specimens, such as the colour of

Table 1. - Details of sample collection where Celleporaria brunnea was found. P, replicates collected at the residential mooring area; TR, replicates collected at the transit mooring area.

\begin{tabular}{|c|c|c|c|c|c|}
\hline Date & Location & Sampling site & Replicates & Latitude & Longitude \\
\hline & \multirow[t]{5}{*}{ La Spezia harbour } & \multirow[t]{5}{*}{ Molo Italia } & $\mathrm{P} 1$ & $44^{\circ} 06^{\prime} 20.75^{\prime \prime} \mathrm{N}$ & 9॰49'49.90’'E \\
\hline 04 June 2010 & & & $\mathrm{P} 2$ & $44^{\circ} 06^{\prime} 19.21^{\prime \prime} \mathrm{N}$ & $9^{\circ} 49^{\prime} 49.73^{\prime \prime} \mathrm{E}$ \\
\hline 23 September 2010 & & & TR1 & $44^{\circ} 06^{\prime} 15.58^{\prime \prime} \mathrm{N}$ & $9^{\circ} 49^{\prime} 55.68^{\prime \prime} \mathrm{E}$ \\
\hline 01 June 2011 & & & TR2 & $44^{\circ} 06^{\prime} 15.67^{\prime \prime} \mathrm{N}$ & 9०49'59.25’'Е \\
\hline 04 October 2011 & & & TR3 & $44^{\circ} 06^{\prime} 15.39^{\prime \prime} \mathrm{N}$ & $9^{\circ} 50^{\prime} 03.15^{\prime \prime} \mathrm{E}$ \\
\hline & \multirow[t]{5}{*}{ Olbia harbour } & \multirow[t]{2}{*}{ Molo Vecchio } & $\mathrm{P} 1$ & $40^{\circ} 55^{\prime} 17.42^{\prime \prime} \mathrm{N}$ & 9॰30'18.33’'E \\
\hline 24 May 2010 & & & $\mathrm{P} 2$ & $40^{\circ} 55^{\prime} 18.34^{\prime \prime} \mathrm{N}$ & $9^{\circ} 30^{\prime} 18.17{ }^{\prime \prime} \mathrm{E}$ \\
\hline 30 September 2010 & & \multirow[t]{3}{*}{ Molo Brin } & TR1 & $40^{\circ} 55^{\prime} 19.36 ” \mathrm{~N}$ & $9^{\circ} 30^{\prime} 30.31^{\prime \prime} \mathrm{E}$ \\
\hline 25 May 2011 & & & TR2 & $40^{\circ} 55^{\prime} 19.95 \% \mathrm{~N}$ & $9^{\circ} 30^{\prime} 28.13^{\prime \prime} \mathrm{E}$ \\
\hline 06 October 2011 & & & TR3 & $40^{\circ} 55^{\prime} 20.44^{\prime \prime} \mathrm{N}$ & $9^{\circ} 30^{\prime} 26.42$ '” \\
\hline & \multirow[t]{5}{*}{ Lampedusa harbour } & \multirow[t]{2}{*}{ Porto Vecchio } & $\mathrm{P} 1$ & $35^{\circ} 29^{\prime} 52.62^{\prime \prime} \mathrm{N}$ & $12^{\circ} 36^{\prime} 28.14^{\prime \prime} \mathrm{E}$ \\
\hline 10 July 2010 & & & $\mathrm{P} 2$ & $35^{\circ} 29^{\prime} 52.86^{\prime \prime} \mathrm{N}$ & $12^{\circ} 36^{\prime} 27.06^{\prime \prime} \mathrm{E}$ \\
\hline 05 September 2010 & & \multirow[t]{3}{*}{ Porto Nuovo } & TR1 & $35^{\circ} 29^{\prime} 47.10^{\prime \prime} \mathrm{N}$ & $12^{\circ} 36^{\prime} 13.56^{\prime \prime} \mathrm{E}$ \\
\hline 22 June 2011 & & & TR2 & $35^{\circ} 29^{\prime} 43.35^{\prime \prime} \mathrm{N}$ & $12^{\circ} 36^{\prime} 13.37^{\prime \prime} \mathrm{E}$ \\
\hline 17 September 2011 & & & TR3 & $35^{\circ} 29^{\prime} 59.31^{\prime \prime} \mathrm{N}$ & $12^{\circ} 36^{\prime} 04.85^{\prime \prime} \mathrm{E}$ \\
\hline
\end{tabular}



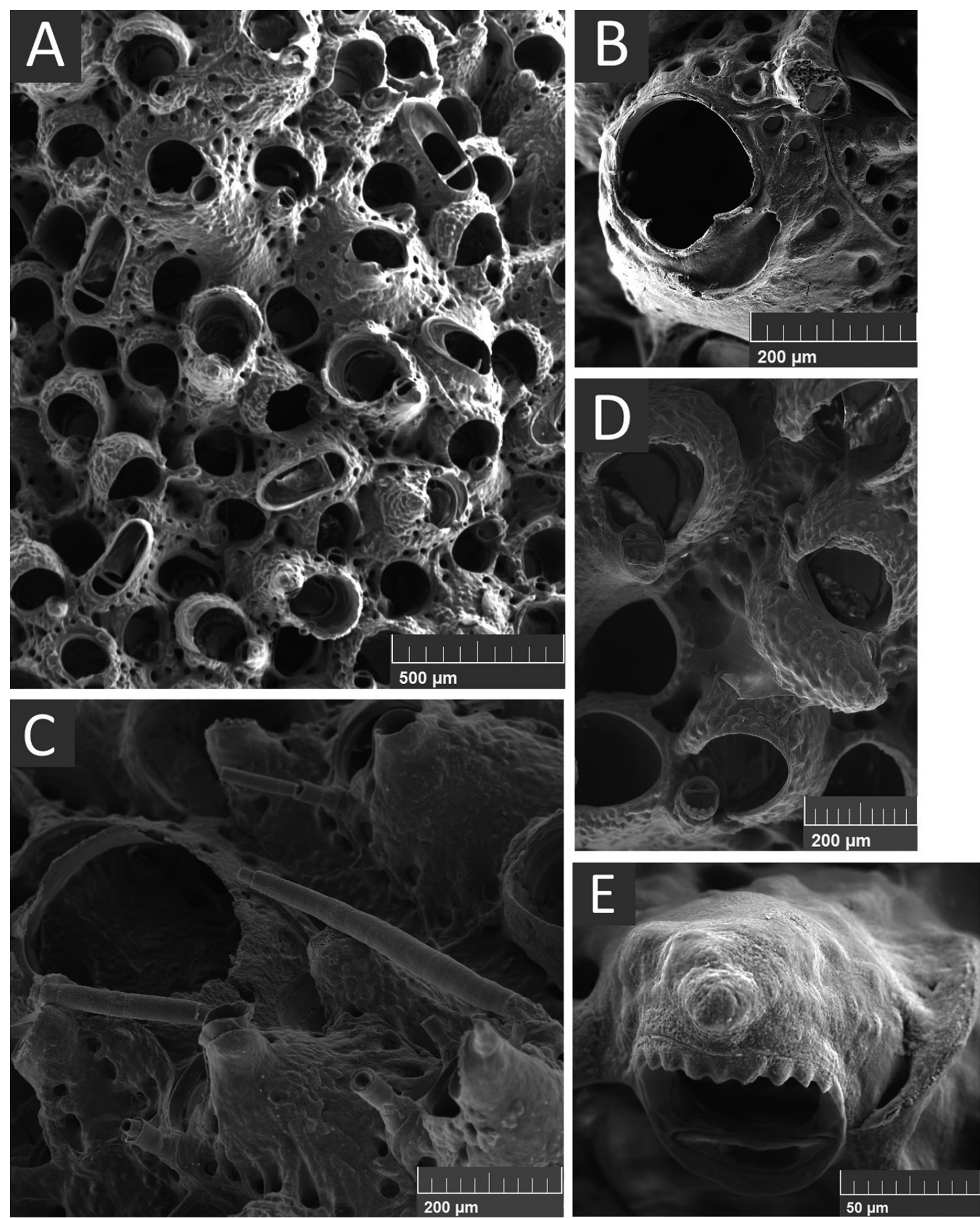

Fig. 4. - Celleporaria brunnea specimens from the western Mediterranean Sea: (A) colony irregular in shape; (B) close-up of the orifice and the areolar pores; (C) close-up of the spines; (D) zooids with suboral avicularia shown both erected and non-erected; (E) close-up of the suboral avicularia with the dentate beak.

the colony, the suboral and interzooecial avicularia, the ooecium and the oral spines, are in accordance with the original descriptions of Hincks (1884) and the later ones of Hastings (1929), Osburn (1952), Soule
(1961), Soule and Soule (1964), Soule et al. (1995), Koçak (2007), Seo and Min (2009), Canning-Clode et al. (2013) and Harmelin (2014). Despite these morphological similarities, a comparison between 

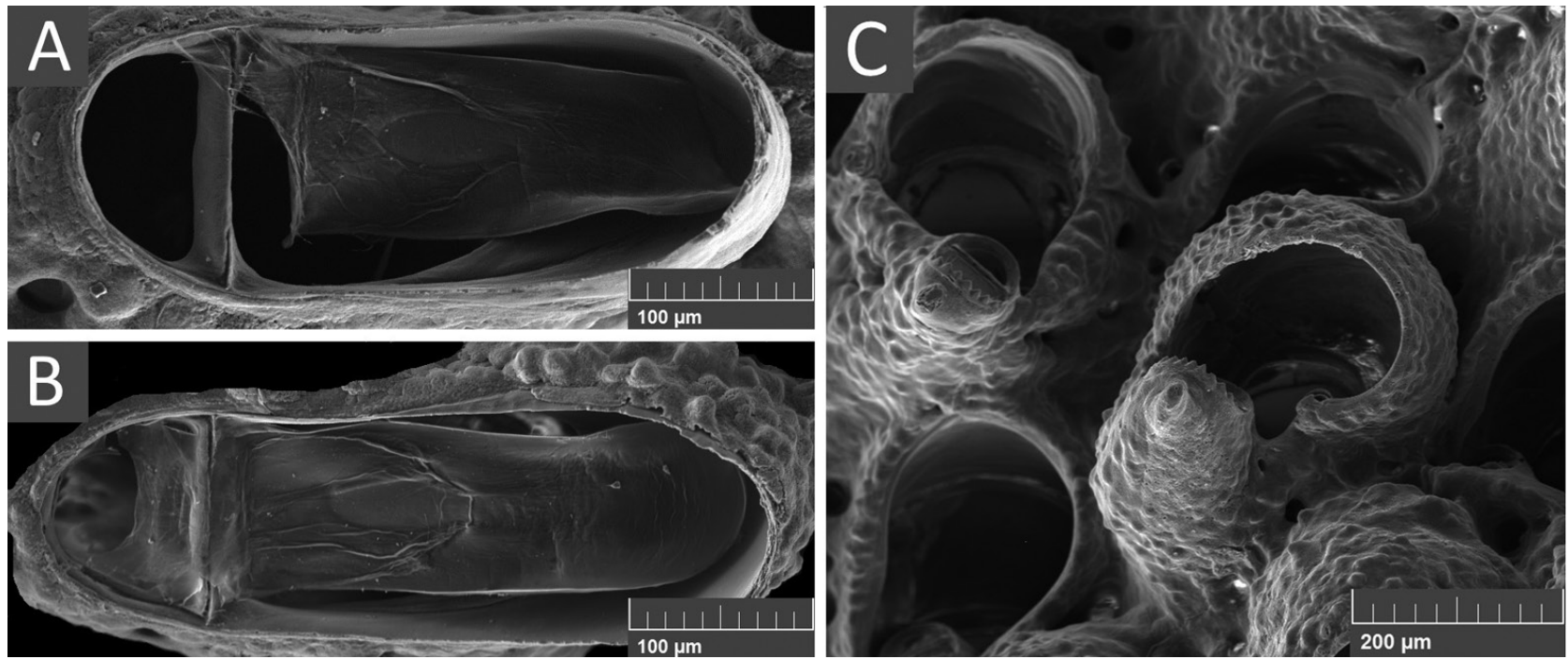

Fig. 5. - Celleporaria brunnea specimens from the western Mediterranean Sea: (A, B) close-up of two interzooidal avicularia; (C) zooids with ovicells.

Table 2. - Interzooidal avicularia and orifice dimensions $(\mu \mathrm{m})$ of Celleporaria brunnea specimens from the harbours of La Spezia, Olbia and Lampedusa. N, number of individuals; sd, standard deviation; min, minimum value; max, maximum value.

\begin{tabular}{|c|c|c|c|c|c|c|c|c|c|c|c|c|c|c|c|}
\hline & \multicolumn{5}{|c|}{ La Spezia harbour } & \multicolumn{5}{|c|}{ Olbia harbour } & \multicolumn{5}{|c|}{ Lampedusa harbour } \\
\hline & $\mathrm{N}$ & average & $\mathrm{sd}$ & $\min$ & $\max$ & $\mathrm{N}$ & average & sd & $\min$ & $\max$ & $\mathrm{N}$ & average & sd & $\min$ & $\max$ \\
\hline Interzooidal avicularia length & 15 & 319.11 & 55.68 & 246.52 & 404.31 & 15 & 299.32 & 52.52 & 237.22 & 437.87 & 15 & 318.53 & 22.65 & 286.19 & 370.61 \\
\hline Interzooidal avicularia width & 15 & 122.62 & 13.30 & 100.42 & 144.41 & 15 & 125.20 & 19.44 & 96.90 & 174.82 & 15 & 123.19 & 20.35 & 92.45 & 160.38 \\
\hline Orifice length & 20 & 149.92 & 12.79 & 131.39 & 177.56 & 20 & 154.42 & 10.39 & 137.22 & 171.38 & 20 & 157.34 & 13.84 & 127.66 & 182.63 \\
\hline Orifice width & 20 & 137.05 & 12.10 & 118.17 & 168.56 & 20 & 138.47 & 12.63 & 106.20 & 160.37 & 20 & 143.46 & 13.05 & 121.45 & 169.73 \\
\hline
\end{tabular}

Table 3. - Average dimensions of interzooidal avicularia and orifice dimensions (um) of Celleporaria brunnea specimens from Osburn (1952), Koçak (2007), Canning-Clode et al. (2013); and of Celleporaria sp. aff. brunnea from Harmelin (2014). Minimum-maximum \pm standard deviation values, are also reported, if available.

\begin{tabular}{lcccc}
\hline & Osburn (1952) & Koçak (2007) & Canning-Clode et al. (2013) & Harmelin (2014) \\
\hline Country & Ecuador & Turkey & Portugal & Lebanon \\
Interzooidal avicularia length & 500 & $328(240-400) \pm 59$ & Unknown & $231(170-340) \pm 70$ \\
Interzooidal avicularia width & 140 & $130(120-140) \pm 10$ & Unknown & $99(80-125) \pm 16$ \\
Orifice length & 160 & $131(110-150) \pm 12$ & $578(711-483) \pm 70.3$ & $167(135-180) \pm 13$ \\
Orifice width & 140 & $154(140-170) \pm 9$ & $394(471-279) \pm 60.7$ & $163(135-180) \pm 14$ \\
\hline
\end{tabular}

our morphometric measurements and literature data has highlighted some differences. Western Mediterranean specimens present an orifice that is variable in size, and clearly longer than broader on average. Orifice measurements are mostly in accordance with those previously reported for $H$. brunnea material from Ecuador (Osburn 1952). On the other hand, orifice measurements of our specimens are different to those of Koçak (2007), Canning-Clode et al. (2013) and Harmelin (2014). Koçak (2007) described the orifice as clearly broader than long, Canning-Clode et al. (2013) reported an orifice that is bigger in size in both length and width and Harmelin (2014) reported similar values for both length and width, with just a slightly longer orifice on average. In our specimens, the interzooidal avicularia are highly variable and show similarities to those measured by Osburn (1952), Winston (1986) and Koçak (2007), but are different from the smaller values described by Harmelin (2014). Furthermore, in the Californian specimens described by Soule et al. (1995), the 'pseudosinus' tends to be closed by small condyles, a feature that was absent in both our specimens and Harmelin's C. sp. aff. brunnea ones (2014).

\section{Distribution}

Native origin. Northeastern Pacific Ocean.

Present distribution. Pacific Ocean (British Columbia, Gulf of California, Panama Canal, Galapagos Islands, Ecuador, Hawaiian Islands, southern Korea), eastern Mediterranean Sea (Turkey and Lebanon coasts) and eastern Atlantic Ocean (Portugal and France coasts).

Occurrence in the western Mediterranean Sea harbours. C. brunnea was well-represented within the fouling community, colonizing both natural and artificial substrates within the three investigated sites. In the harbours of La Spezia and Olbia, it mainly grows on the bivalve Mytilus galloprovincialis, which was the dominant species of the fouling assemblages. Thriving colonies of $C$. brunnea were found on both shell surface and often on mussel byssal threads. Besides mussels, the species occurred on other biotic substrates, such as the polychaete dwelling-tubes of Sabella spallanzanii (Gmelin, 1791) and Hydroides spp. Gunnerus, 1768 
and on the ascidian Styela plicata (Lesueur, 1823). In Lampedusa harbour, the species was mostly discovered growing directly on the concrete dock walls, as well as on the red algae Ellisolandia elongata (J. Ellis and Solander) K.R. Hind and G.W. Saunders, 2013, which dominated the benthic community. The abundance of $C$. brunnea and of the associated bryozoans communities in the three harbours investigated are shown in Table 4. In La Spezia harbour, 19 species of bryozoans were identified. C. brunnea was not particularly abundant (ab. index: $+/++$ ) but always present during the two sampling years (2010-2011), and did not display differences between seasons. In the harbour of Olbia, 15 species of bryozoans were identified, and an increasing abundance of $C$. brunnea was recorded during the two autumn months of sampling, especially in 2011 (September 2010: maximum ab. index ++, and October 2011: maximum ab. index ++++). In Lampedusa, 16 bryozoan species were identified; there was a higher abundance of C. brunnea in 2011 (especially in September, maximum ab. index: ++++$)$ compared with the 2010 sampling (maximum ab. index: ++).

\section{DISCUSSION}

Celleporaria brunnea colonies found in our samples were well-developed, forming large coarse incrustations and irregular masses, bearing ovicells, thus confirming that the species was well-acclimated and reproducing. The presence in three distant localities of the western Mediterranean Sea of established populations, whose abundance increased during the two years of observation, indicates the probability of further records in this area.

In the Mediterranean Sea and Atlantic Ocean, $C$. brunnea was reported from harbours and marinas, showing a preference for both natural (e.g. mussel beds and seaweeds; Koçak 2007) and artificial hard substrates (e.g. docks and PVC plates; Canning-Clode et al. 2013, present study). Port systems are known to be highly disturbed environments subject to high propagule pressure of non-indigenous species, due to the presence of a variety of anthropogenic pathways (Smith et al. 1999, Ruiz et al. 2000, OcchipintiAmbrogi and Savini 2003). Amongst these, shipping activity, for both commercial and tourism purposes, facilitates the introduction in new regions and the subsequent spread of non-indigenous organisms fouling on the hulls of ships or transported in ballast waters or sea chests (Carlton 1985, 1987, Carlton and Geller 1993). Like many marine sessile organisms, bryozoans are capable of using a variety of potential dispersal mechanisms, as they demonstrate great catholicity in their exploitation of substrates. Man-made installations located in major shipping ports and centres for pleasure craft can provide a wide and extensive range of hard surfaces for attachment that include breakwaters, pontoons and pilings, which constitute a suitable habitat for sessile organisms such as bryozoans (Glasby and Connell 1999, Connell 2000, 2001). C. brunnea was found in the mooring area of the Italian harbour of La Spezia, Olbia and Lampedusa, in the Portuguese marina of Cascais (Canning-Clode et al. 2013) and on artificial substrates in Turkey (Koçak 2007) and Lebanon (Harmelin 2014). Ship fouling, in particular, could provide a very rapid, reliable means of dispersal and is likely to be an effective vector for both local and global scales (Watts et al. 1998). Thus, hull fouling is the most likely vector of introduction and spread of $C$. brunnea in the Mediterranean Sea and the Atlantic Ocean. Similarly, Godwin (2003) suggested that the species may have been secondarily dispersed to the Hawaiian Islands via hull fouling of ships travelling from the Gulf of California, where C. brunnea was already known to occur. Although such dispersal will mostly be restricted to ports, other transport mechanisms may also increase the geographic range of bryozoan species beyond these points of entry, including rafting on floating materials (e.g. marine debris of anthropogenic origin, such as floating plastics) and drifting seaweeds (Watts et al. 1998, Barnes 2002); in recent years, marine debris has increased significantly, and this floating material is used as a 'hitchhiking' substrate for mature individuals of different taxa, bryozoans included (Barnes 2002, Aliani and Molcard 2003).

In addition, transport by ballast water has to be considered as a potential dispersal mechanism, since bryozoans are able to foul the inside of ballast tanks (Carlton 1985). In fact, larval forms and development traits are crucial in contributing to dispersal and habitat exploitation of marine invertebrates (Scheltema 1986a,b, Roughgarden et al. 1988). For instance, larvae of the cheilostome bryozoan Membranipora membranacea (Linnaeus, 1767) were found in ballast water (Carlton and Geller 1993), but the dispersal possibilities of this bryozoan is enhanced due to the long pelagic duration of its planktotrophic (cyphonautes) larva (Ryland 1964, Yoshioka 1982, Stricker et al. 1988). Conversely, C. brunnea has a lecithotrophic (coronate) larva with a wide area of coronal cells for ciliary propulsion and a short pelagic duration (Santagata and Zimmer 2000, Santagata 2008a,b). The low dispersal potential of $C$. brunnea larvae is thus not very effective in long-range transportation of the species, e.g. in ship ballast waters. The short pelagic duration of $C$. brunnea larvae, which can settle within a few hours of their release, means that they may not be able to disperse over long distances and their transfer in ballast waters can be considered effective just for short-range transportation. Furthermore, C. brunnea was also found on aquaculture steel cages in Korea (Seo and Min 2009); this vector has to be taken into account in the light of the records from Arcachon Basin (André et al. 2014), Olbia and La Spezia (present work), all of which are intense mariculture activity sites. The transfer as nontarget species associated with mussels and clams for aquaculture purposes cannot be excluded as a potential vector of introduction, albeit a less effective one.

Current distribution and record dates of C. brunnea in the Mediterranean Sea might suggest a step-by-step anthropogenic route of invasion: firstly, long-distance introduction from the Pacific, most probably through shipping via the Suez Canal, to the Levantine basin, including the Lebanese and Turkish findings, followed 
270 A. Lodola et al.

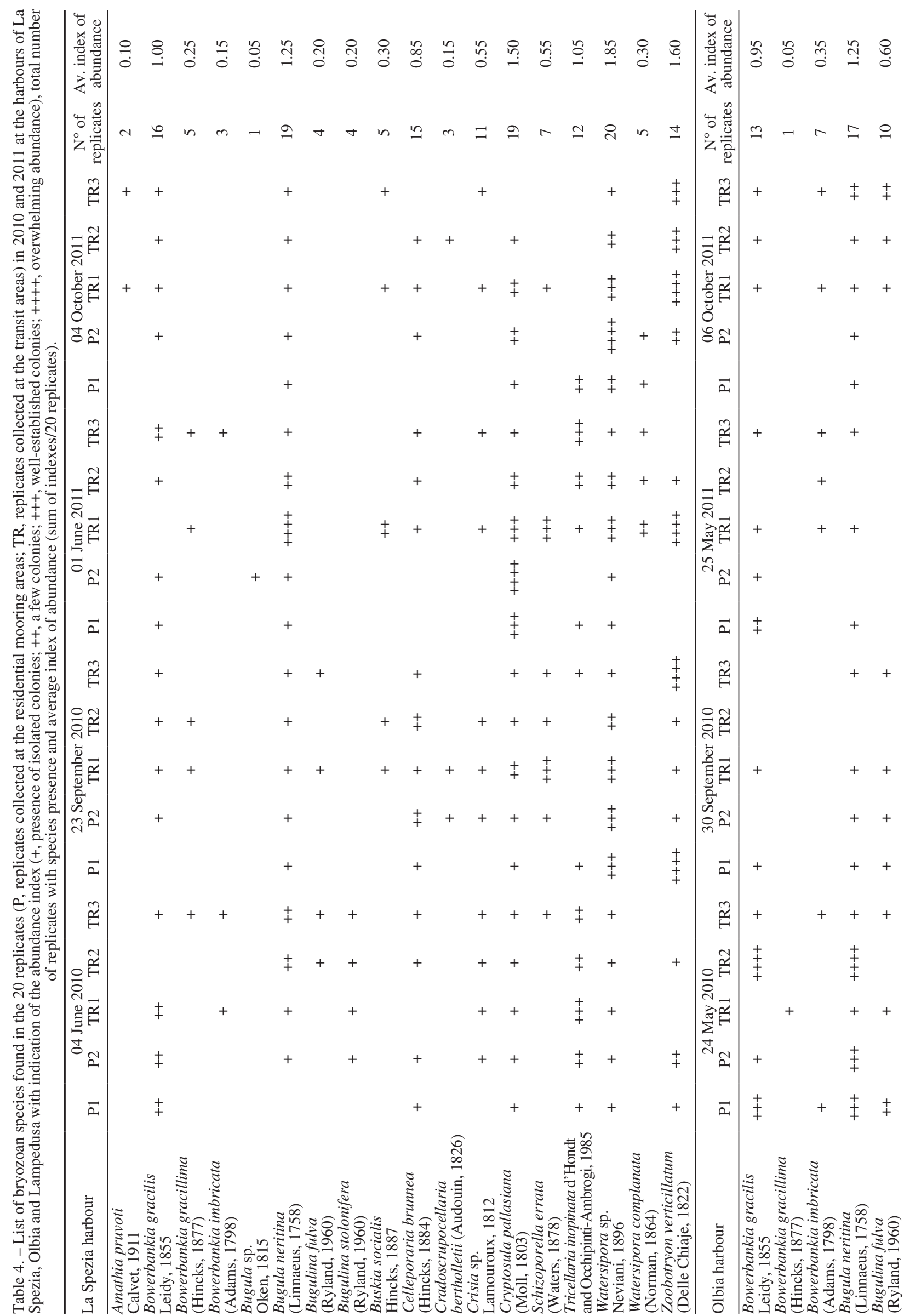




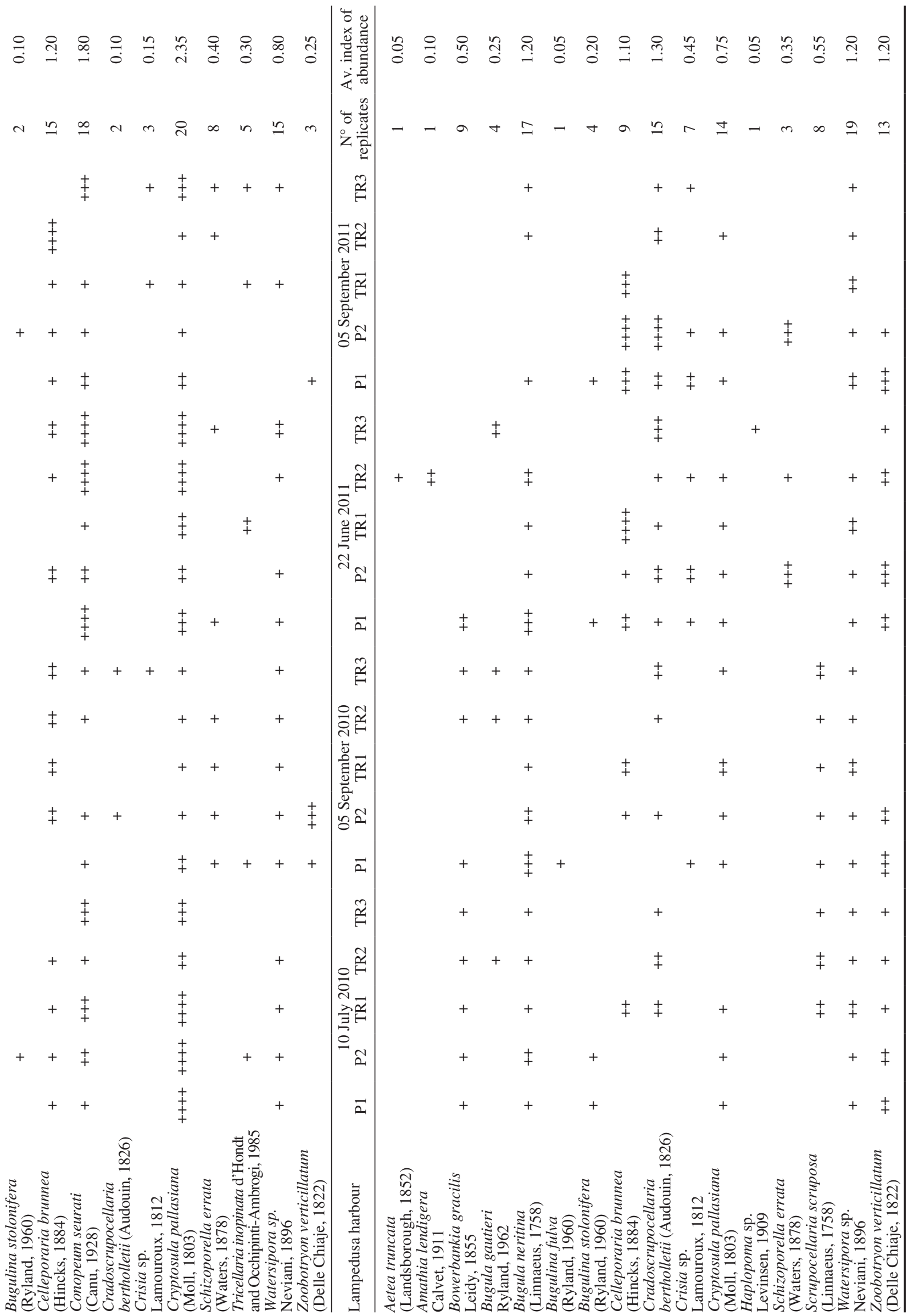


by a stepping stone occurrence in the Sicilian Channel (Lampedusa harbour). This fact might have contributed to the further spread of the species northwards, up to the Tyrrhenian (Olbia harbour) and the Ligurian Sea (La Spezia harbour), as well as eastwards towards the Atlantic coast of Portugal (Cascais marina) and France (Arcachon Basin). The presence of $C$. brunnea in the polluted inner part of Izmir Bay near Alsancak harbour (Turkey) suggests that the most likely pathway of the species' introduction in the eastern Mediterranean Sea is the hull fouling community of ships (Koçak 2007) originating from the Pacific through the Suez Canal. This is also the most likely explanation for C. brunnea occurrence along the Lebanese coast (Harmelin et al. 2009), as the location of the Levantine Basin "downstream" of the opening of the Suez Canal facilitates Indo-Pacific biota in becoming established first along the eastern Mediterranean coasts (Galil 2009). From there, C. brunnea might have been subsequently transferred and spread throughout the Mediterranean by carriers of different types (e.g. vessels and cruise liners). These operate all over the basin as far east as the Aegean and Levantine Seas, as far north as the Tyrrhenian and the Ligurian Sea and eastwards up to the Alboran Sea towards the northern Atlantic Ocean (www.biodivalue. eu; Accessed October 2014).

However, the taxonomic comparison between our morphometric measurements and literature data allowed us to assert a greater similarity with the Pacific specimens of $C$. brunnea, rather than with the Mediterranean Sea or Atlantic Ocean ones. Given these circumstances, an alternative hypothesis for the introduction route of this bryozoan to the western Mediterranean Sea appears to be more likely than the first one. Firstly, C. brunnea might have reached La Spezia harbour by means of cargo ships which travel regularly from the Pacific to the Ligurian Sea and back (www. porto.laspezia.it; accessed October 2014). In this case, La Spezia harbour would represent the first event of introduction into the western Mediterranean basin and the primary source for further events of secondary spread within the whole basin. While big tankers and merchant ships originating from the Pacific could have introduced the first propagules of $C$. brunnea into La Spezia waters, coaster and pleasure boats could have contributed to the secondary spread of the species southwards to Olbia harbour in the western-central Tyrrhenian Sea and to Lampedusa Island in the Sicilian Channel. Indeed, these localities are situated in areas with extremely heavy tourist traffic and feature busy marinas and moorings for pleasure boats and fast ferries; recreational boating was recently accepted as an important secondary transmission vector of nonindigenous species worldwide (Johnson et al. 2001, Floerl and Inglis 2003, Davidson et al. 2010, Clarke Murray et al. 2011). Because of the morphometric differences of the eastern Mediterranean Sea and Atlantic Ocean specimens, the occurrence of $C$. brunnea there has to be considered the result of multiple introduction events, possibly unrelated to the events of primary and secondary introduction in the western Mediterranean basin.
In La Spezia harbour, $C$. brunnea is the most frequent and abundant bryozoan, along with other bryozoan species (Table 4): the cosmopolitan Bugula neritina (Linnaeus, 1758), Bowerbankia gracilis Leidy, 1855, Cryptosula pallasiana (Moll, 1803), Watersipora sp. Neviani, 1896, the pseudo-indigenous (sensu Carlton 2009) Zoobotryon verticillatum (Delle Chiaje, 1822) and the non-indigenous Tricellaria inopinata d'Hondt and Occhipinti-Ambrogi, 1985. Table 4 shows that, when there was a high abundance of $C$. brunnea in Olbia harbour, other encrusting bryozoans such as Conopeum seurati (Canu, 1928) and C. pallasiana were less abundant or absent, and vice versa. In Lampedusa harbour, the most common assemblage of bryozoans included $B$. neritina, Cradoscrupocellaria bertholletii (Audouin, 1826), Watersipora sp. and Z. verticillatum together with $C$. brunnea, which generally displayed higher abundances in the summer of 2011 than in the summer of 2010. Furthermore, C. brunnea prevailed in samples collected at the end of the summer season in the three sampling locations during both years, while it was less abundant and frequent in samples collected in spring (Table 4). Unfortunately, the lack of previous bryozoan collection in the three Italian harbours makes it difficult to precisely assess the invasion history of $C$. brunnea in the western Mediterranean Sea and to make inferences about its effects on the native bryozoan community. The time of introduction of $C$. brunnea to La Spezia, Olbia and Lampedusa is unknown and the species might have remained unnoticed for a long time. Notwithstanding this, $C$. brunnea has been found to be widespread and abundant in the three investigated harbours since 2010, therefore suggesting that its introduction and acclimation in these areas can be definitely backdated.

The differences in taxonomic characteristics of specimens found in different areas may indicate multiple introduction events, and not just a single event of primary introduction followed by secondary spread. However, only a taxonomic review of the Celleporaria genus and genetic and taxonomic analysis of $C$. brunnea specimens, together with a comparison with Hincks's type (Hincks 1884), would allow us to reconstruct the historical introduction events of $C$. brunnea, and to determine whether the morphological differences between specimens are to be assigned to a complex of species or a variation within the $C$. brunnea species.

The species belonging to the Celleporaria genus are known to be highly opportunistic and invasive (Dunstan and Johnson 2004), and their occurrence in harbours or marinas may indicate a tolerance capacity to thrive in polluted water conditions (Harmelin 2014). Thus, $C$. brunnea and the other congeneric species may be expected to occur in other localities throughout the Mediterranean Sea in the years to come.

\section{ACKNOWLEDGEMENTS}

The authors thank Dr. Maria Pia Riccardi of the CISRiC-Arvedi Laboratory (University of Pavia) for her technical assistance in the elaboration of SEM pictures and the Association For-Mare for supporting this research. 


\section{REFERENCES}

Agius C., Schembri P.J., Jaccarini V. 1977. A preliminary report on organisms fouling oyster cultures in Malta (Central Mediterranean). Mem. Biol. Mar. Oceanogr. 7: 51-59.

Aliani S., Molcard A. 2003. Hitch-hiking on floating marine debris: macrobenthic species in the Western Mediterranean Sea. Hydrobiologia 503: 59-67. http://dx.doi.org/10.1023/B:HYDR.0000008480.95045.26

André F., Corolla J.-P., Lanza B., Rochefort G. 2014. Bryozoaires d'Europe: Les Carnets du Plongeur. Éditions Neptune Plongée, Gargas, 256 pp.

Barnes D.K.A. 2002. Invasions by marine life on plastic debris. Nature 416: 808-809. http://dx.doi.org/10.1038/416808a

Boero F. 1994. Fluctuations and variations in coastal marine environments. Mar. Ecol. 15(1): 3-25. http://dx.doi.org/10.1111/j.1439-0485.1994.tb00038.x

Canning-Clode J., Souto J., McCann L. 2013. First record of Celleporaria brunnea (Bryozoa: Lepraliellidae) in Portugal and in the East Atlantic. Mar. Biod. Rec. 6: 1-5. http://dx.doi.org/10.1017/S1755267213000821

Carlton J.T. 1985. Transoceanic and interoceanic dispersal of coastal marine organisms: the biology of ballast water. Oceanogr. Mar. Biol. Annu. Rev. 23: 313-371.

Carlton J.T. 1987. Patterns of transoceanic marine biological invasions in the Pacific Ocean. Bull. Mar. Sci. 41(2): 452-465.

Carlton J.T. 2009. Deep invasion ecology and the assembly of communities in historical time. In: Rilov G., Crooks J.A. (eds), Biological invasions in marine ecosystems. Springer-Verlag Berlin Heidelberg, Ecological Studies 204, pp. 13-56. http://dx.doi.org/10.1007/978-3-540-79236-9 2

Carlton J.T., Geller J.B. 1993. Ecological roulette: biological invasions and the global transport of non-indigenous marine organisms. Science 261: 78-82. http://dx.doi.org/10.1126/science.261.5117.78

Carlton J.T., Hodder J. 1995. Biogeography and dispersal of coastal marine organisms: experimental studies on a replica of a 16th century sailing vessel. Mar. Biol. 121: 721-730. http://dx.doi.org/10.1007/BF00349308

Clarke Murray C.C., Pakhomov E.A., Therriault T.W. 2011. Recreational boating: a large unregulated vector transporting marine invasive species. Divers. Distrib. 17: 1161-1172. http://dx.doi.org/10.1111/j.1472-4642.2011.00798.x

Connell S.D. 2000. Floating pontoons create novel habitats for subtidal epibiota. J. Exp. Mar. Biol. Ecol. 247: 183-194. http://dx.doi.org/10.1016/S0022-0981(00)00147-7

Connell S.D. 2001. Urban structures as marine habitats: an experimental comparison of the composition and abundance of subtidal epibiota among pilings, pontoon and rocky reefs. Mar. Environ. Res. 52: 115-125. http://dx.doi.org/10.1016/S0141-1136(00)00266-X

Davidson I.C., Zabin C.J., Chang A.L., et al. 2010. Recreational boats as potential vectors of marine organisms at an invasion hotspot. Aquat. Biol. 11: 179-191. http://dx.doi.org/10.3354/ab00302

d'Hondt J.L. 1988. Bryozoa from the coast of Israel. Italian J. Zool. 55(1-4): 191-203. http://dx.doi.org/10.1080/11250008809386617

Dunstan P.K., Johnson C.R. 2004. Invasion rates increase with species richness in a marine epibenthic community by two mechanisms. Oecologia 138: 285-292. http://dx.doi.org/10.1007/s00442-003-1400-7

Floerl O., Inglis G.J. 2003. Potential for the introduction and spread of marine pests by private yachts. Hull fouling as a mechanism for marine invasive species introductions. In: Godwin L.S. (ed) Proceedings of a workshop on current issues and potential management strategies. Honolulu, Hawaii, 12-13 February 2003, 22-28.

Floerl O., Inglis G.J., Dey K., et al. 2009. The importance of transport hubs in stepping-stone invasions. J. Appl. Ecol. 46: 37-45. http://dx.doi.org/10.1111/j.1365-2664.2008.01540.x

Galil B.S. 2009. Taking stock: inventory of alien species in the Mediterranean Sea. Biol. Invasions 11: 359-372. http://dx.doi.org/10.1007/s10530-008-9253-y

Glasby T.M., Connell S.D. 1999. Urban structures as marine habitats. Ambio 28: 595-598.

Godwin S.L. 2003. Hull fouling of maritime vessels as a pathway for marine species invasion to the Hawaiian Islands. Biofouling 19: $123-131$. http://dx.doi.org/10.1080/0892701031000061750

Gollasch S. 2002. The importance of ship hull fouling as a vector of species introductions into the North Sea. Biofouling 18(2): $105-121$. http://dx.doi.org/10.1080/08927010290011361

Gollasch S., Lenz J., Dammer M., et al. 2000. Survival of tropical ballast water organisms during a cruise from the Indian Ocean to the North Sea. J. Plankton Res. 22(5): 923-937. http://dx.doi.org/10.1093/plankt/22.5.923

Harmelin J.G. 2014. Alien bryozoans in the eastern Mediterranean Sea - new records from the coast of Lebanon. Zootaxa 3893(3): 301-338.

http://dx.doi.org/10.11646/zootaxa.3893.3.1

Harmelin J.G., Bitar G., Zibrowius H. 2009. Smittinidae (Bryozoa, Cheilostomata) from coastal habitats of Lebanon (Mediterranean Sea), including new and non-indigenous species. Zoosystema 31(1): 163-187. http://dx.doi.org/10.5252/z2009n1a9

Hastings A.B. 1929. Cheilostomatous Polyzoa from the vicinity of the Panama Canal collected by Dr. C. Crossland on the cruise of the S.Y. "St. George". Proc. Zool. Soc. London 99(4): 697-740. http://dx.doi.org/10.1111/j.1096-3642.1929.tb01453.x

Hincks T. 1884. Report on the Polyzoa of the Queen Charlotte Islands. Part 3. Ann. Mag. Natur. Hist. Ser. 5. 13: 49-58.

Johnson L., Ricciardi A., Carlton J.T. 2001. Overland dispersal of aquatic invasive species: a risk assessment of transient recreational boating. Ecol. Appl. 11(6): 1789-1799. http://dx.doi.org/10.1890/1051-0761(2001)011[1789:ODOAIS 12.0.CO;2

Koçak F. 2007. A new alien bryozoan Celleporaria brunnea (Hincks, 1884) in the Aegean Sea (eastern Mediterranean). Sci. Mar. 71(1): 191-195.

Lodola A. 2013. Xenodiversity in Marine Protected Areas: three case studies in Italy. PhD Thesis. Pavia Univ. Italy, 243 pp.

Lodola A., Savini D., Occhipinti-Ambrogi A. 2012. First record of Tricellaria inopinata (Bryozoa: Candidae) in the harbours of La Spezia and Olbia, Western Mediterranean Sea (Italy). Mar. Biod. Rec. 5: 1-7. http://dx.doi.org/10.1017/S1755267212000309

Marchini A., Gauzer K., Occhipinti-Ambrogi A. 2004. Spatial and temporal variability of hard-bottom macrofauna in a disturbed coastal lagoon (Sacca di Goro, Po river delta, north-western Adriatic Sea). Mar. Pollut. Bull. 48(11-12): 1084-1095. http://dx.doi.org/10.1016/j.marpolbul.2003.12.015

Minchin D. 2007. Rapid coastal survey for targeted alien species associated with floating pontoons in Ireland. Aquat. Invasions 2(1): 63-70. http://dx.doi.org/10.3391/ai.2007.2.1.8

Occhipinti-Ambrogi A. 1991. The spread of Tricellaria inopinata into the Lagoon of Venice: an ecological hypothesis. Bull. Soc. Sci. Nat. Ouest Sér. 1: 299-308.

Occhipinti-Ambrogi A. 2000. Biotic invasions in a Mediterranean Lagoon. Biol. Invasions 2: 165-176. http://dx.doi.org/10.1023/A:1010004926405

Occhipinti-Ambrogi A., Savini D. 2003. Biological invasion as a component of global change in stressed marine ecosystems. Mar. Pollut. Bull. 46: 542-551. http://dx.doi.org/10.1016/S0025-326X(02)00363-6

O'Donoghue C.H., O'Donoghue E. 1926. A second list of the Bryozoa (Polyzoa) from the Vancouver Island region. Contrib. Can. Biol. Fish. 3(1): 47-131. http://dx.doi.org/10.1139/f26-003

Osburn R.C. 1952. Bryozoa of the Pacific coast of America, Part II, Cheilostomata Ascophora. Allan Hancock Pac. Exped. 14(2): 271-611.

Powell N.A. 1969. Indo-Pacific bryozoans new to the Mediterranean coast of Israel. Isr. J. Zool. 18: 157-168.

Roughgarden J., Gaines S., Possingham H. 1988. Recruitment dynamics in complex life cycles. Science 241: 1460-1465. http://dx.doi.org/10.1126/science.11538249

Ruiz G.M., Fofonoff P.W., Carlton J.T., et al. 2000. Invasion of coastal marine communities in North America: apparent patterns, processes, and biases. Annu. Rev. Ecol. Syst. 31: 481-531. http://dx.doi.org/10.1146/annurev.ecolsys.31.1.481

Ryland J.S. 1964. The identity of some cyphonautes larvae (Polyzoa). J. Mar. Biol. Ass. UK 44: 645-654. http://dx.doi.org/10.1017/S002531540002782X

Santagata S. 2008a. The morphology and evolutionary significance of the ciliary fields and musculature among marine bryozoan larvae. J. Morphol. 269: 349-364. 
http://dx.doi.org/10.1002/jmor.10592

Santagata S. 2008b. Evolutionary and structural diversification of the larval nervous system among marine bryozoans. Biol. Bull. 215: 3-23.

http://dx.doi.org/10.2307/25470679

Santagata S., Zimmer R.L. 2000. Comparing cell patterns of coronate bryozoan larvae with fluorescent probes. In: Herrera Cubilla A., Jackson J.B.C. (eds), Proceedings of the Eleventh International Bryozoology Association Conference, Smithsonian Tropical Research Institute, Balboa, Republic of Panama, 26-31 January 1998. Smithsonian Tropical Research Institute, pp. 365-375.

Savini D., Marchini A., Forni G., et al. 2006. Touristic harbours and secondary spread of alien species. Biol. Mar. Mediterr. 13 760-763.

Scheltema R.S. 1986a. Long-distance dispersal by planktonic larvae of shoal-water benthic invertebrates among Central Pacific Islands. Bull. Mar. Sci. 39(2): 241-256.

Scheltema R.S. 1986b. On dispersal and planktonic larvae of benthic invertebrates: an eclectic overview and summary of problems. Bull. Mar. Sci. 39(2): 290-322

Sciberras M., Schembri P.J. 2007. A critical review of records of alien marine species from the Maltese Islands and surrounding waters (Central Mediterranean). Medit. Mar. Sci. 8(1): 41-66. http://dx.doi.org/10.12681/mms.162

Seo J.E., Min B.S. 2009. A faunistic study on Cheilostomatous Bryozoans from the shoreline of South Korea, with two new species. Korean J. Syst. Zool. 25(1): 19-40. http://dx.doi.org/10.5635/KJSZ.2009.25.1.019

Smith L.D., Wonham M.J., McCann D.L., et al. 1999. Invasion pressure to a ballast-flooded estuary and an assessment of inoculant survival. Biol. Invasions 1: 67-87. http://dx.doi.org/10.1023/A:1010094527218

Soule J.D. 1961. Results of the Puritan-American Museum of Natural History Expedition to western Mexico, 13. Ascophoran
Cheilostomata (Bryozoans) of the Gulf of California. Am. Mus. Novit. 2053: 1-65.

Soule D.F., Soule J.D. 1964. The Ectoprocta (Bryozoa) of Scammon's Lagoon, Baja California, Mexico. Am. Mus. Novit. 2199: $1-56$

Soule D.F., Soule J.D., Chaney H.W. 1995. The Bryozoa. In: Blake J.A., Chaney W., Scott P.H., et al. (eds), Taxonomic atlas of the benthic fauna of the Santa Maria Basin and the western Santa Barbara Channel. Irene McCulloch Foundation Monograph Series No. 2. Hancock Institute of Marine Studies, Southern California Univ. Press, 344 pp.

Stricker S.A. Reed C.G., Zimmer R.L. 1988. The cyphonautes larva of the marine bryozoan Membranipora membranacea. I. General morphology, body wall, and gut. Can. J. Zool. 66(2): 368-383. http://dx.doi.org/10.1139/z88-054

Watts P.C., Thorpe J.P., Taylor P.D. 1998. Natural and anthropogenic dispersal mechanisms in the marine environment: a study using cheilostome Bryozoa. Philos. Trans. R. Soc. Lond. B. 353: $453-464$ http://dx.doi.org/10.1098/rstb.1998.0222

Winston J.E. 1986. An annotated checklist of coral-associated bryozoans. Am. Mus. Novit. 2859: 1-39.

Woollacott R.M., Zimmer R.L. (eds). 1977. Biology of bryozoans. Academic Press. 584 pp.

Yoshioka P.M. 1982. Role of planktonic and benthic factors in the population dynamics of the bryozoan Membranipora membranacea. Ecology 63, 457-468. http://dx.doi.org/10.2307/1938963

Zenetos A., Gofas S., Morri C., et al. 2012. Alien species in the Mediterranean Sea by 2012. A contribution to the application of European Union's Marine Strategy Framework Directive (MSFD). Part 2. Introduction, trends and pathways. Medit. Mar. Sci. 13(2): 328-352. http://dx.doi.org/10.12681/mms.327 